\title{
İkinci Çocukluk Dönemindeki Çocukların Oyun Mekanları ve Örgün Eğitim İlişkisi
}

\author{
Relationship Between Playgrounds of the Second Childhood Period \\ and Primary Education
}

\section{Mukaddes ÇIRAK YILMAZ * İbrahim BAKIR **}

Öz: Oyun; çocukluk döneminin vazgeçilmezi olarak, çocuk mekanı tasarımlarında yer alan en temel fonksiyondur. Oyun mekanları da bu fonksiyon çerçevesinde şekillenir, düzenlenir ve nitelik kazanır. Özellikle İkinci Çocukluk dönemi (6-11 yaş dönemi) çocukların oyun ihtiyacının çevresel oyun alanları kadar temel eğitim aldıkları kurumlara ait mekanlarda da çözümlenmesi gerekmektedir. Bu çalışma, ikinci çocukluk döneminde olan çocukların kullandıkları oyun alanlarındaki mekânsal düzenleme ve kurgunun öneminin vurgulanması amacıyla yapılmıştır. Çalışma kapsamında çocuklar için "oyun" ve "oyun mekanları" konuları üzerine bir literatür taraması yapılmış; oyunun mekansal karşılığının sağlanabilmesine yönelik tasarım ve kriterler belirlenmiş ve bu mekanların örgün eğitimdeki yeri üzerine bir değerlendirme yapılmıştır.

Anahtar sözcükler: Çocuk Oyun Alanları, Okul Oyun Mekanları, Çocuk Mekanları, Oyun

\begin{abstract}
Play is the most essential function of childhood. Also, playgrounds are the most indispensable spaces for children. Playgrounds are shaped, regulated, and qualified within this function. In particular the play needs of second childhood period children (the period between the ages of 6-11), should be solved in the places of the institutions where they receive basic education as well as in environmental playgrounds. This study aims to emphasize the importance of spatial arrangement and fiction in those playgrounds used by second childhood period children. Within the scope of this study, literature research on "play" and "playgrounds" for children was conducted. Consequently design and criteria were determined to provide the spatial formation of play; and an assessment was also made concerning the place of these spaces in primary education.
\end{abstract}

Keywords: Children Playground, Playground Spaces for School, Spaces of Children, Play

\section{Giriş}

'Çocuk' mekan kavramının hakkını en etkin şekilde veren kullanıcıdır. Çünkü 'Çocuk olmak' "İnsanı çevreden belli bir ölçüde ayıran ve içinde eylemlerini sürdürmesine elverişli olan boşluk" (Hasol, 2002) olarak tanımlanan mekanı her yönüyle kullanmaktır. Bu kavram insanın çevre ile karşl1ıklı etkileşimi sonucunda içinde yaşadığ hissedilen etkisi nispetinde de değerlendirilmektedir. Tinsel bir kavram olarak da ele alınabilen

* Doktora Öğrenci, Akdeniz Üniversitesi, Fen Bilimleri Enstitüsü, Mimarlık Anabilim Dalı, Antalya. mukaddescirak@gmail.com, https://orcid.org/0000-0001-6054-1376

** Dr. Öğr. Ü., Akdeniz Üniversitesi Mimarlık Fakültesi, Mimarlık Bölümü, Antalya. ibakir@akdeniz.edu.tr, https://orcid.org/0000-0001-8493-5345 
mekan ile ilgili olarak F. Ching;

"Mekan sürekli olarak varlığımızı sarıp sarmalar. Mekansal hacim boyunca hareket eder, biçim ve nesneleri görür, sesleri duyar esintiyi hisseder ve bahçede açan çiçeklerin kokusunu alırız" (Ching, 2004)

değerlendirmesini yapmaktadır. Öyle ki; mekanların en hayalperest niteleyicisi ve en aktif öznesi 'Çocuk', çocuğun mekana yüklediği en temel fonksiyon ise 'Oyun' olmaktadır. UNICEF (UNESCO) ve IPA (International Play Association) çocukların oyun hakkı ve oyun alanları hakkı kapsamında çocuk haklarıyla ilgilenen iki uluslararası kuruluş olarak 1959 yılında Birleşmiş Milletler İnsan Hakları Yasası ile bağlantılı birer Çocuk Hakları Bildirgesi yayınlanmışlardır. Bu bildirgenin 7. maddesi oyun alanları düzenlemekle ilgili olarak topluma yüklenen bir sorumluluk ortaya koymakta ve şu ifadelere yer vermektedir:

"Çocuğa ĕgitimde olduğu gibi, oyun oynamada da tam firsat tanınmalıdır; toplum ve kamusal otorite bu hakk yerine getirmeye çalışmalıdır” (Tekkaya, 2001).

Ayrıca çocukların oyun oynama hakları uluslararası yasalarla güvence altına alınmış ve yapılan sözleşmeler Türkiye tarafından da kabul edilmiştir. Birleşmiş Milletler Genel Kurulunca 20 Kasım 1989 tarihinde onaylanan Çocuk Hakları Sözleşmesi, 1995 y1lı 22184 sayılı Resmî Gazetede yayınlanarak yürürlüğe girmiştir. Bu sözleşmenin 31. maddesinin birinci fikrasında;

"Taraf devletler çocuğun dinlenme, boş zaman değerlendirme, oynama ve yaşına uygun eğlence etkinliklerinde bulunma, kültürel ve sanatsal yaşama serbestçe katılma hakkın tanırlar" ifadesi yer almaktadır (Erişim, https://www.unicef.org/turkey/crc/). Çocuk gelişimi ve eğitiminde önemli bir yere sahip olan 'Oyun' üzerine çok farklı tanım ve görüşler olmakla birlikte bazıları aşağıdaki şekilde sıralanabilir;

"Oyun, Çocukluk döneminin temel amacıdır"

"Oyun, Öğrenme, yaratma, deneyim kazanma, iletişim kurma ve yetişkinliğe hazırlanma aracıdır" (Erişim, https://www.ekipnormarazon.com/Makalelerimiz/Oyun-VeCocuk (Norma Razon, Eğitim Danışmanı - Pedagog Okul Öncesi Eğitimde Oyunun, Oyunda Yetişkinin İşlevi).

"Oyun, çocuğun kendisini ifade etmesidir"

"Oyun, çocuğun işidir"

"Oyun, hayal ile gerçek arasında bir köprüdür"

"Oyun, çocuğun iç dünyasını yansıtan bir aynadır" (Ormanlığlu Uluğ, 1999)

"Oyun evrensel bir kavramdır ve çocuk bulunan her yerde oyun vardır" (Kök et al.2007)

"Oyun; çocuğun fikir ve karakterini güçlendiren, ona neşe ve haz veren, vücut gelişiminde önemli rol oynayan içgüdüsel hareketlerdir"

"Oyun; gönüllü ve özgürce yapılan, mutluluk kaynağı olan, çocuğun tüm gelişim yüzlerini uyaran, yetenekleri kadar duyuları ve duygulart geliştiren etkinliklerin tümüdür” (Erişim, https://www.egitimgen.com/2019/03/30/egitimde-oyun-ve-etkileri).

Çocukluk dönemi olarak belirtilen yaşlar çocuk gelişim uzmanlarınca erken (ilk) çocukluk dönemi (3-6 yaş) ve ikinci çocukluk dönemi (6-11 yaş) olarak iki kategoride ele alınmaktadır. Özellikle okul öncesi dönemden başlayarak çocukluk döneminde gelişim psikolojisi, öğrenme psikolojisi, eğitim psikolojisi gibi alanlar üzerine yapılan araştırmalar oyunun en temel öğrenme arac1 olduğunu belirtmektedirler. Eğitimde oyun ve etkileri üzerine çalışmalar yürüten Kuran (2019) oyun oynamanın ilköğretim çağındaki çocukların temel ihtiyaçlarından biri olduğunu vurgulayarak; bu ihtiyacın giderilmemesi ya da kısıtlanması durumunda, toplumun çekirdeğini oluşturan çocukların sağlıklı bir gelişim sergileyemeyeceğini çünkü çocukların oynadıkları 
rollerle ileriki yaşamları için deneyim kazandığını, zekâ, kişilik ve becerilerin oyun oynayarak geliştiğini belirtmektedir (Erişim, https://www.egitimgen.com/2019/03/30/egitimde-oyun-ve-etkileri). İlk çocukluk dönemi oyunla daha iç içe yaşayan çocuklar, ikinci çocukluk dönemlerinde yaş olarak örgün eğitimin başlaması ile bu ihtiyaçlarını kurumlar dahilinde çözülmüş mekanlarda, genel anlamda eğitim-öğretim aralarında yada okul dışı zamanlarda gidermek durumundadırlar. Bununla birlikte oyunu temel eğitimin bir parçası olarak uygulayan ülkeler de giderek çoğalmaktadır. Amerika' da kurulmuş bir vakıf olan National Association for the Education of Young Children (Küçük çocukların eğitimi ulusal birliği) kendi sitesinde 'Oyunun Bir Çocuk için Değeri' üzerine şu değerlendirmeyi yapmıştır:

"Oyun; Çocukların bilişsel becerilerini (mesela bir market taklidi yaparak hesap ve problem çözmesi), fiziksel yeteneklerini (mesela blokları dengelemek ve oyun parkında koşmak gibi), yeni kelime haznelerini (mesela oyuncak dinozor ile oynaması gerektiğinde ögrendiği gibi), sosyal becerilerini (mesela bir araba yıkama oyununda diğer çocuklarla birlikte oynayarak), okuma becerilerini (mesela bir restoranda menü oluşturmak gibi) öğretir ve geliştirir”. (Erişim, www.naeyc.org National Association for the Education of Young Children, USA).

Oyunun eğitsel bir öğrenme aracı olarak kullanılması ile ilgili olarak Kök ve arkadaşları (2007) ise çocuğun oyunda duygusal tepkilerini ortaya koymakla kendisini tanıma firsatı bulmasının yanında kendini kontrol edebilme becerisini de kazandığını belirtmiştir. Çünkü çocuğun bütün gelişim alanlarını etkileyen oyun, çocuk için vazgeçilmez öğrenme aracı olarak kabul edilmiştir. Öyle ki; çevreyi tanımada, diğer insanlarla ilişki kurmada çocuğun oyun içinde sosyalleştiği belirtilmiş, oyunun sadece çocuğun gelişim alanlarını etkilemekle kalmayan, aynı zamanda öğretmene, aileye vb. kişilere çocuğu tanıma ve anlama ortamı sunan bir etkinlik olduğu vurgulanmıştır (Kök et al.2007).

Okul çağı çocuklarının oyun kavramına ilişkin algılarının ve oyun tercihlerinin değerlendirilmesine yönelik bir çalışma sonucunda İlköğretim çağındaki çocukların herhangi bir aktivitenin oyun olup olmadığına karar verirken 'Eğlenmek' temel ölçütünü kullandıkları belirlenmiştir (Pilten \& Pilten 2013). Dolayısıyla 'Oyun' kelimesi çocuklukla eşdeğer bir terim olarak kullanılmaktadır. Çünkü oyun çocuklar için bir nevi yaşam, yaşamsa çocuklar için oyun demektir. Çocuklar için hazırlanmış oyun mekânları da bu açıdan önemlidir ve üzerinde çalışmayı gerekli kılmaktadır.

Bu çalışma; ikinci çocukluk dönemi çocuklarının kullandıkları oyun alanlarındaki mekânsal düzenleme ve kurgunun öneminin vurgulanması amacıyla yapılııştır. Çalışma kapsamında çocukların oyun mekanları üzerine yapılmış araştırma ve çalışmalar; oyunun mekansal karşılığını sağlayabilmek adına ihtiyaca cevap verebilir nitelikte iyi tasarlanmış mekanlar elde etmek için tasarım standart ve kriterleri yönünden değerlendirilmiştir.

\section{Oyunların Mekansal Karşılığı}

Mekan veya oyun alanı çevresi oyun potansiyeli üzerinde etkili olmaktadır. Çocukta mekân bilincinin oluşması, algı ve motor gelişiminin uyarılması ve farklı mekan deneyimlerine bağlı olarak mekan duygusu gelişmektedir (Tekkaya 2001). Bu da mekan geometrisini oluşturan mekan sınırlayıcılarının, yüzeylerin biçim, doku ve renklerinin ve mekandaki donatı elemanlarının bir bütün halinde mekanın niteliğini oluşturması ve algılanması ile olmaktadır. Ayrıca mekan öncelikle görme duyusu ile algılandığı için, o mekanı aydınlatan ışığın yön ve kalitesi de mekanın niteliğini oluşturmada önemli bir faktördür (Altan 2005). Yani mekanın görsel özellikleri mekansal niteliği belirlemektedir. Bu özellikler kısaca biçim, oran ve ölçek, donanım sayısı, doku ve malzeme, renk ve ışık şeklinde tanımlanmakta; mekan ve içindekilerin 
kullanımına bağlı olarak nitelenmektedir (Çırak 2008). Dolayısıyla her mekân eğitim için bir potansiyele sahiptir. Bu anlamda oyun alanı çocuğa biçim, boyut, sayı, parçalar arası ilişki vb. gibi kavramları geliştirmesi için de yardımcı olmalıdır (Tekkaya 2001).

Çocuk mekanları iç veya diş mekanlarda çözümlenebilir. Her iki durumda da kötü tasarlanmış mekan çözümleri ya da bina bölümlerinin çocuğun olumsuz yönde gelişme riskini ve gerilimini artırdığından söz etmek mümkündür. Buna karşılık iyi tasarlanmış mekanların çocuğun bedensel ve ruhsal açıdan olumlu gelişmesini desteklediğinden; algısal ve bilişsel gelişimini hızlandırdığından veya öğretici ve eğitici roller oynayarak olumlu davranışlarını pekiştirdiğinden ve kaza riskini azaltarak yaşamsal bir rol oynadığından da söz edilebilir (Gür \& Zorlu 2002). Dolayısıyla mimarinin çocuk gelişimi üzerindeki etkisi de bu bakımdan dikkate alınmalıdır. Çocukların kullandığı mekânlar denince akla ilk gelen oyun mekanlarıdır ve geneli itibari ile dış mekanda çözümü psikolog ve gelişim uzmanlarınca da daha doğru bulunduğu için 'Oyun Alanları' olarak ifade edilmektedir. Açık havada oynanan oyunların önemi üzerine hazırladığı çalışmada Balkış (2019) açık hava oyunlarının çocuklarda doğal ortamın çevrenin ve iklim bilincinin farkındalığını sağladığını, bu durumun da çocuğun sosyal ve fiziksel gelişimini olumlu etkilediğini ifade etmekte ve çocukların açık havada oynamaları gerektiğini vurgulamaktadır. Bununla birlikte günümüz şehir anlayışında özellikle güvenlik gibi sebeplerle yapı iç mekanlarında oyun mekanı çözümleri de giderek artmaktadır. Ayrıca belirtmek gerekir ki; tüm oyun alanlarının oyun ekipmanları içermesi gibi bir gereklilik de yoktur. Çoğu zaman boş ve serbest oyunlara bırakılmış alanlar çocuklar açısından özgürce kendi oyunlarını kurmalarına olanak sağlamaktadır. Çünkü oyun kurmak zaten çocuğun doğasında var olan bir eylemdir. Çocukların iç ya da dış mekanlarda oynadığı oyun türleri ve buna bağlı oyun kalitesi de değişmektedir. Bu bakımdan amaç ve yararlarına göre oyun türleri pasif, aktif yaratıcı, düşsel ve bilişsel olarak beş gruba ayrılmaktadır (Gür \& Zorlu 2002). Gür ve Zorlu'ya göre bunlar;

Pasif Oyunlar: Çocuğun az ve hafif hareketlerle gerçekleştirdiği, toplumsal ilişkiye dayalı oyun ve iletişim türlerini kapsayan, öğrenilmiş zihinsel etkinlikleri içeren oyunlardır. Mesela karş1lıklı öykü anlatmak, kitap, pul gibi nesneleri değiş tokuş etmek, şiir-şarkı sözü ezberlemek taklit yapmak gibi...(Fig. 1-2)

Aktif Oyunlar: Fiziksel ak-

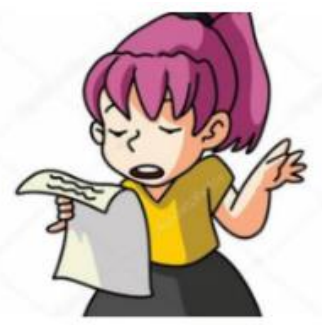

Fig. 1.

http://drneclayazicioglu.meb.k1 2.tr/icerikler/2d-siir-okumaetkinligi_6421049.html

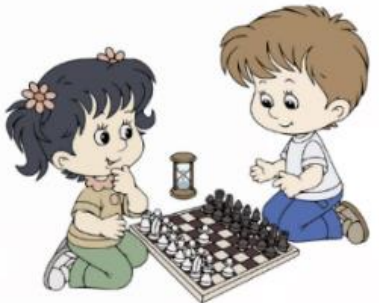

Fig. 2.

https://publicdomainvectors.or $\mathrm{g} / \mathrm{tr} /$ bedava-vektor/Satrançoynayan-çizgi-filmçocuklar/ 60923.html tiviteye dayalı oynanan oyunları kapsamaktadır. Bu açıdan hareket ve enerjiye dayalı büyük ölçüde örgütlü olan oyunlardır. Mesela jimnastik ve spor türleri, saklambaç, yakantop oynamak gibi... (Fig. 3-4). 


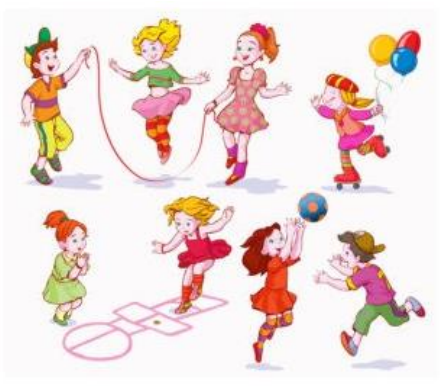

Fig. 3.

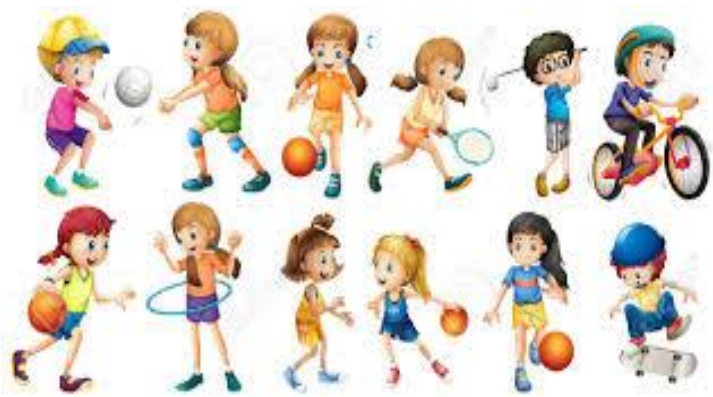

Fig. 4.

https://hareketlioyunornekleri.word https://fr.123rf.com/photo_34646081_illustrationpress.com/oyunun-onemi/

des-enfants-faire-du-sport-différent.html

Yaratıcı Oyunlar: Çevre olanaklarını ve eldeki mevcutları amaçları dışında değerlendirmeye dayalı olarak oynanan oyunlardır. Mesela buruşturulup yuvarlanmış bir malzemeyi top olarak kullanmak, tencere ve tabakları çalgı aleti yapmak, kalıp veya elle çamura şekil vermek, kumdan şekiller yapmak ve malzemeleri farklı oyun araçlarına çevirmek gibi... (Fig. 5-6).

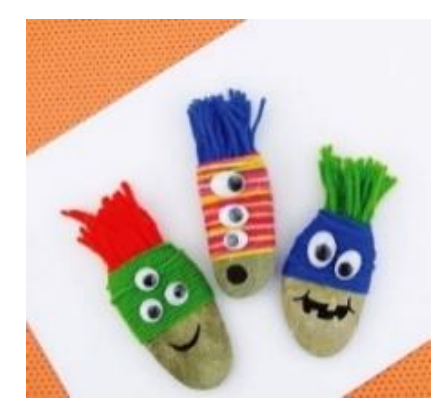

Fig. 5

https://hadiyapalimanne.wordpr ess.com/2015/09/21/tastansevimli-canavarlar/

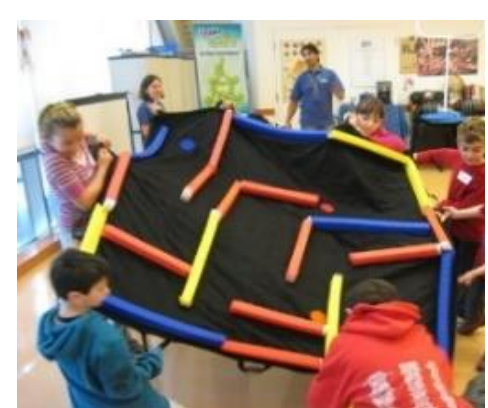

Fig. 6

https://hanoiskyteam.com/tea mbuilding-tre-em-va-nhungtro-choi-vui-gan-ket/

Düşsel Oyunlar: Çocuğun tanık olduğu olaylar, dinlediği masallar, okuduğu romanlar ve izlediği filmlerden etkilendikleri kişilikleri günlük yaşama aktarmasından dolayı ortaya çıkan oyunlardır. Mesela hırsız-polis oyunları, meslekler, çizgi karakter taklitleri, şerif-kovboy oyunlar1 gibi...(Fig. 7-8)

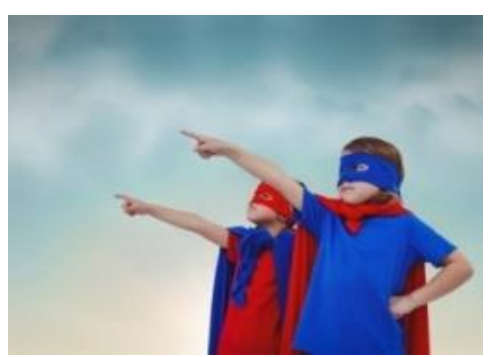

Fig. 7.

https://okul.com.tr/okuloncesi/makaleleri/okul-oncesioyunlar-ve-faydalari-292

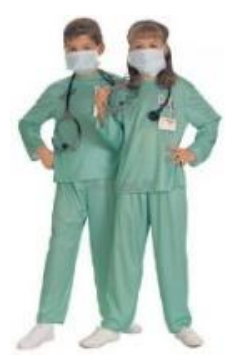

Fig. 8.

https://www.partiyildizi.com/d oktor-cocuk-kostumu 
Bilișsel Oyunlar: Çoğu özellikle akıl ve zeka oyunları olarak bilinirler. Araştırma ve keşfe yönelik risk alma- deney yapma, akıl yürütme ve mantığı etkin bir şekilde kullanma, problemler karşısında strateji geliştirme gibi etkinliklerin ortaya konma biçimleridir. Mesela robotik kodlama, yapboz, satranç, bir mağarayı keşif ve çeşitli gereçlerin onarımı gibi... (Fig. 9-10).

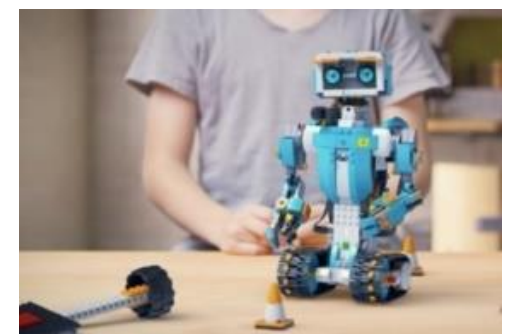

Fig. 9.

https://www.cocukyeri.com/etkinli k/milo-robotik-kodlama-atolyesi1001

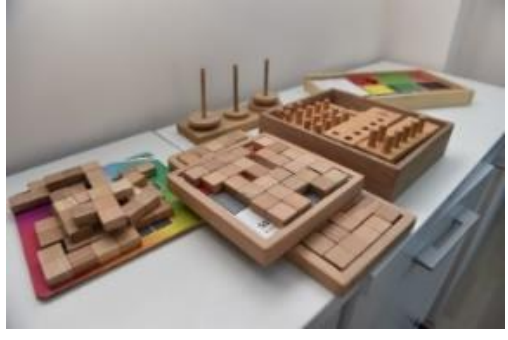

Fig. 10.

http://eski.canakkale.bel.tr/assets/ph oto/kreszekaoyunlari10102016/kres zekaoyunlari101020164

Ayrıca belirtmek gerekir ki; örgün eğitimde öğretmenler eğitimli oyun lideri rolünü üstlenmektedirler. Bu açıdan eğitim kurumlarında oyuna ayrılan süre ilk çocukluk dönemine göre az olsa da eğitimli oyun liderlerince kurgulanan oyunlar çocukların kaliteli oyun oynaması açısından avantaj kabul edilebilir. Fanuscu (1994) eğitimli oyun liderleri kavramı üzerine belirli, sistemli ve bir kuruma bağlı olduğundan bahsederek oyunun kalitesine dikkat çekmiştir. Bu anlamda Heseltine ve Holborn'a dayanarak Fanusçu (1994) oyunun kalitesini aşağıdaki tanımlara bağlı kılmıştır:

Zaman: Oyun alanındaki oyunun değeri çocuğun dikkatini tekrarlı olmayan bir oyun aktivitesine verdiği süre kadar artmaktadır.

Değiștirilebilirlik: Oyun mekanında, oyun alanı ve oyun elemanlarının geliştirilebilmesi bakımından değiştirilebilir olması oyun çeşitliliğini sağlamaktadır. $\mathrm{Bu}$ da oyunun değerini artmasını sağlayıcı bir durumdur.

İlgi: Oyun alanı ve oyun elemanının çocuğun bireysel ihtiyaçlarına cevap verebilecek ölçüde ve yakınlıkta olması oyunun değerini artırmaktadır.

Olasılıklar: Oyun alanının çocuğa sunduğu olasılıklar arttığı ölçüde oyunun değeri artış göstermektedir.

Uygunluk: Oyun alanının farklı yaş grubuna ve bu yaş gruplarının oyun ihtiyaçlarına cevap verebildiği oranda oyunun değeri artmaktadır.

İşbirliğgi: Oyun alanı ve oyun elemanları grup oyunlarını ve işbirliğini teşvik ettiği ölçüde oyun değerinin artacağı belirtilmektedir (Fanuscu, 1994).

\subsection{Mekansal Karşııı̆ı̀n Sağlanması}

Oyun alanları tasarımında, oyunların mekansal karşılı̆̆ tasarım kriterlerinin belirlenmesi ve etkin bir fizibilite çalışmasını gerektirir. Bunun için de belirli standart ve kriterlerin yerine getirilmesi gerekmektedir. Dolayısıla oyunun mekansal karşılığının sağlanması da bu standart ve kriterlerin yerine getirilme ölçüsüne bağlıdır. Bu açıdan oyunların mekansal karşılığının sağlanmasına yönelik standart ve kriterler aşağıdaki şekilde sıralanabilir:

1. Öncelikle mekan seçimi yapılmalı, dıș veya iç mekanda tasarlanacak oyun alanı kullanıcı sayısına uygun büyüklükte olmalıdır. Yerleşim yerleri ve çevresinde çocuklar için ayrılan dış mekan oyun alanları için belirlenmiş metrekare standartları ölçü kabul edilebilir. $\mathrm{Bu}$ standartlar ülkelere göre de farklılık göstermektedir. Mesela; Amerika'daki oyun alanları; 
çocuk bahçesi-ilkokul birlikteliği ve çocuk bahçesi-park birlikteliği şeklindedir. Almanya'da oyun ve çocuk bahçeleri için kişilik 0.5-2.4 m2 gibi bir değer öngörülürken; Avusturalya'da 5000 kişinin yaşadığı bir mahallede oyun alanı olarak $14.000 \mathrm{~m} 2$ önerilmiștir. Fransa'da kent içi oyun alanlarında çocuk bașına beș m2, serbest oyun alanlarında ise çocuk başına $10 \mathrm{~m} 2$ oyun alanı önerilirken; İngiltere'de çocuk başına düșen oyun alanı $24.1 \mathrm{~m} 2$ olmaktadır (Anon'dan aktaran Y1lmaz ve Bulut, 2003). Ülkemizde ise dış mekan çocuk oyun alanları, 'Çocuk Bahçesi' olarak ele alınmakta, alan ihtiyaçları ise kent plâncılarına göre değişiklik göstermektedir. Apartman tipi yerleşimin olduğu yerlerde çocuk bahçesinin $1000 \mathrm{~m} 2$ 'den az olmaması gerekli görülmekle birlikte bazı araştırmacılara göre her çocuk için $6,5 \mathrm{~m} 2$ alan ayrılarak en küçük çocuk bahçesinin $250 \mathrm{~m} 2$ 'den küçük olmaması ve yerleşim alanı büyüdükçe 250-1000 m2'ye kadar genişlemesi önerilmektedir (Uzun'dan aktaran Y1lmaz ve Bulut,2003). 02.09.1999 tarihinde yayınlanan 23804 sayılı 'İmar Planı Yapılması ve Değişikliklerine Ait Esaslara Dair Yönetmelikte Değişiklik Yapılması Hakkında Yönetmelik' ile yeșil alan standardı $10 \mathrm{~m} 2$ 'ye çıkarılmıştır. Bu duruma göre, 5000 kişilik ilköğretim ünitesi düzeyinde $1,5 \mathrm{~m} 2$ /kişi büyüklüğünde çocuk bahçesi, 15000 kişilik mahalle ünitesi düzeyinde $2 \mathrm{~m} 2$ /kişi mahalle parkı ve $2 \mathrm{~m} 2$ /kişi spor alanı olmak üzere toplam $4 \mathrm{~m} 2 /$ kişi yeşil alan ve 45000 ve üzeri nüfuslu kent ünitesi düzeyinde ise 3,5 $\mathrm{m} 2$ /kiși büyüklüğünde kent park1 ve $1 \mathrm{~m} 2$ /kişi büyüklügünde spor alan1 olmak üzere toplam 4,5 m2 /kişi yeşil alan öngörülmüş̧ür (Aksoy, 2014). Çocukların ihtiyacı olan oyun alanlarının yerinde ve yeterli çözümü tüm oyun alanlarında olduğu gibi örgün eğitimde de bu duyarlılığı gerektirmektedir. Bunun için M.E.B. İnşaat ve Emlak Daire Başkanlığı en son 2015 yılında revize edilen eğitim yapılarının hazırlanmasında asgari tasarım standartları kılavuzunu yayınlamıştır (Erişim, https://iedb.meb.gov.tr /meb_iys_dosyalar/2015_08/17032245_2015asgaritasarmklavuzu.pdf). Bu kılavuzla eğitim yapıları için tasarım ölçütlerinin belirlenmesi ve önceden yapılmış ya da yeni yapılacak yapıların belirli standartlar çerçevesinde tutulması hedeflenmiştir. Kılavuzda oyun mekanı tanımlarına anaokulu yapılarında faaliyet ve oyun odaları, oyun parkı ve bahçesi olarak yer verilirken; ilköğretim yapılarında oyun yerine ders etkinlik ve serbest zaman mekanları tanımlanmıştır. $\mathrm{Bu}$ açıdan kişi başı $1.6 \mathrm{~m} 2$ standardı getirilen dersliklerin eğitimli oyun liderleri olan öğretmenlerce zaman zaman pasif oyunlar için kullanılabileceği düşünülmelidir. Bununla birlikte derslikler haricinde resim odası (Kişi başı min. $1.86 \mathrm{~m} 2$ ), müzik odası (Kişi başı min. $1.80 \mathrm{~m} 2$ ), fen ve teknoloji laboratuvarı (Kişi baş1 min. $1.86 \mathrm{~m} 2$ ), Kütüphane (Kişi başı min. $1.3 \mathrm{~m} 2$ ), okuma salonu (Kişi başı min. 1.5m2), Audio ve İnternet salonu (Kişi başı min. 1.5m2), M.E.B. İhtiyaç programında belirtilen ölçüde çok amaçlı salon, sahne, kapalı spor alanları, kapalı teneffüshane... gibi özel, ek etkinlik ve eğlence mekanları oluşturulabilmektedir. Okul bahçesi ise açık alan düzenlemeleri, sosyal alanlar ve kentsel donatılar, açık spor alanları ile birlikte gezinti ve yürüme yollarını kapsamaktadır. Açı alan düzenlemeleri mümkün olduğunca arazinin yapısına uymaya çalışmalı, açık spor alanlarında ise en az 1 adet kuzey-güney doğrultuda basketbol- voleybol sahası bulunmalı asgari standartları getirilmiştir. Ayrıca sosyal alanlar ve kentsel donatılar olarak; tören alanı, en az iki sınıfın dersine imkan sağlayan amfi tiyatro, satranç sahası, ilkokullar için seksek oynama sahası vb. geleneksel oyunlar için ayrılmış alanlar, oturma grupları gibi mimari ve kentsel donatıları (bank, çöp kutuları, su sebilleri vb.) içinde barındıracak alanların tasarlanması gerekli kılınmıştır. Bu alanların peyzaj düzenlemesi içerisinde oturma grupları, yürüyüş ve gezinti yolları ve buna ek olarak eğitim programına uygun şekilde öğrencilerin doğayı deneysel olarak tanıyabilecekleri ekim alanları oluşturulması istenmektedir. Bunlara ek olarak ise arsa konumundan kaynaklanan kot farklarına \%6 eğime sahip rampalar gerekli görülmektedir.

2. Oynanacak oyun türlerine göre mekan, malzeme ve ekipman seçimi yapılmalıdır. Özellikle iç mekan oyun alanlarında farklı ve birbirinden bağımsız oyunlar veya oyun dışı mekanlar arasında çevre etkileşimi sağlayacak ses yalıtım, akustik gibi unsurların düşünülmesi 
gerekmektedir. Bu durum oyun verimliliği ve konsantrasyon açısından önemlidir. Oyun alanı tasarımı farklı aktivitelerin ayrılmış ancak birbiriyle ilişkili bir bölgelemesi şeklinde de olabilir. Bu durumda ise oyun alanları arasında çocuk seçim yapabilmeli ve en sessiz olan aktiviteyi merkeze yerleştirip, aktif olanlar çeperlerde yer almalıdır (Cohen'den aktaran Tekkaya, 2001). Ayrıca çocukların oyun yada oyuncaklara ulaşımı kolay ve gerektiğinde sökülüp takılabilir olmalıdır.

3. Mekan içindeki ekipmanlar ve bunların ölçüleri ya da oyunu sağlayacak çizgi ve şekiller gibi oyun düzenlemeleri çocuk açısından ergonomik ölçüde olmalıdır. Çocukların hareket kapasitesi, fiziksel güç ve objelere olan ilgisi çocuğun yaşına ve cinsiyetine göre değişmektedir (Ayan ve Ulaş, 2015). Oyun alanlarının mekânsal özellikleri de bu ölçüde kullanıcıya yönelik değişkendir. Mekandaki bu değişkenler kullanıcıya uygun ölçüde olmalıdır. Bu durum M.E.B. ilköğretim kurumları yönetmeliğince (Erişim, M.E.B. ilköğretim kurumları yönetmeliği http://mevzuat.meb.gov.tr/dosyalar/1703.pdf) de zorunlu tutulmuştur.

4. Oyun alanı tasarımlarında peyzaj unsurları dikkate alınmalıdır yada oluşturulmalıdır. Mümkün olduğunca doğal unsurların kullanıldığı (peyzaj kullanımı) açık hava oyun mekânları oluşturmak çocuklar için en uygun oyun alanları kabul edilmektedir. Öyle ki; çocuklar için oyun mekânı olarak doğal bir mekânın, küçük bir ormanın seçildiği bir çalışmada, bu mekânların çocukların geleneksel oyun mekânlarındaki eksikliklerini gidermedeki rolü araştırılmıştır. Araştırma sonucunda doğal peyzaj alanlarının, çocukların ihtiyaçlarına cevap verir nitelikte olduğu ortaya çıkmıștır. Doğal mekânlarda yapılan bu çalıșmada; eğimli alanların, geniş çim alanların ve bitkiler içeren oyun mekânlarının çocukların vücut (motor) gelişiminde etkili olduğu vurgulanmaktadır (Yılmaz \& Bulut 2003). Ayrıca oyun alanlarında doğru bitki kullanımı çocukların fiziksel, zihinsel ve duygusal gelişimlerine önemli katkıları olduğu gibi, bu mekânlarda sıkça görülen kazaları ve yaralanmaları en aza indirdiği de belirtilmektedir (Duman \& Koçak 2013).

5. Oyun alanı ve ekipmanların çocuk kullanımına uygun özellikte olması, yüzeylerin kayma, düşme, yaralanma gibi kazalara karşı mümkün olduğunca güvenli ve doğal malzemeden seçilmesi önemlidir. Organik gevşek dolgular (odun yongası, ağaç kabuğu, yapay ahşap lifi gibi), inorganik dolgular (çakıllar, kum, ezilmiş mermer gibi) ve imal edilmiş ürünler (dökme kauçuk, mikro bileşenler, gevşek kauçuklar gibi) özellikle diş mekan oyun alanlarında kullanılabilecek malzemelerdir (Ayan \& Ulaş 2015). Ancak iç mekan çözümlerinde ise hijyen kurallarının ön plana çıkması bu durumu daha çok sert plastik malzeme kaynaklı oyun araçları ve antibakteriyel, antistatik özellikte ve zehirli gaz salınımı olmayan olan pvc esaslı duvar boya yahut döşeme kaplama elemanlarına yönlendirmektedir. Benzer şekilde çocuk oyun elemanlarında kullanılan malzemelerin de genel olarak plastik, geri dönüşümlü ve yüksek yoğunluklu polietilen (HDPE), ahşap, kauçuk, galvanize çelik, laminat (HPL) olduğu belirtilmektedir (Korkmaz 2009).

6. İklim koșulları mekan tasarımlarında ana etkenlerden biridir ve iklime uygun mekan çözümleri olușturulmalıdır. Oyun mekanlarında özellikle dış mekanlarda mekansal yönelme, iklim koşullarına uygun yüzey ve kaplama malzemeleri seçilmesi, mekan koruyucu elemanları gibi düzenlemeler düşünülmelidir. Bu durum iç mekan oyun alanlarında daha çok iklimsel konfor açısından ele alınmakta ve 1sıtma-soğutma elemanları, nem konforu, gölgelik ve güneş kırıcılar... gibi konfor sağlayıcı elemanların düzenlenmesi ile olmaktadır. Özellikle dış mekan oyun alanları tüm yıl boyunca kullanılabilir nitelikte olmalıdır. Bu açıdan hava şartlarına korunaklılık sağlanmalıdır. Ayrıca hem iç hem de dış mekanlardaki oyun alanlarında sürekli bakım problemi oluşturacak malzeme ve araç seçilmemesine dikkat edilmelidir. Bu açıdan öncelik sağlıklı ve ekonomik olduğu kadar uzun ömürlü malzeme seçilmesidir. M.E.B. eğitim yapıları asgari tasarım standartları kılavuzunda iklim yönünden mekan yönelimlerinin nasıl olması gerektiğini ülkemizde bulunan temel dört iklim bölge- 
sine göre ayrınt1lı olarak belirtmektedir (Erişim, https://iedb.meb.gov.tr/meb_iys_dosyalar/ 2015_08/17032245_2015asgaritasarmklavuzu.pdf).

7. Renk kullanımı oyun alanlarında önemli bir kriterdir. Mekandaki fonksiyonla da ilişkili olarak çocuklara olumlu etki edecek renklerin seçilmesi önemlidir. Çocukların ruh hallerine göre renk seçtiğini belirten araştırmalardan söz edilmekte ve bu durumun oyun alanlarında duyguları ve tepkileri uyarma ve güçlendirme amacıyla kullanılabilir olduğu ifade edilmektedir (Alqudah 'tan akt. Ünal 2009). Renkli oyuncakların çekiciliği kadar renkli mekanların çekiciliği de çocuk için yadsınamaz bir gerçektir.

8. Mekanın ya da mekan içi ekipmanların biçimsel yapısı çocuklar için ilgi çekici olarak kullanılabilir bir özelliktir. Mekansal düzenleme veya ekipmanlarda yaş gruplarının en çok ilgilendiği temel geometrik şekillerin, masal karakteri, çizgi karakterler, oyuncaklar... Vs. gibi çocuksu gereçlerin ve çalışmaların mekan içinde biçimsel varlığı mekana olan ilgiyi artırabilme potansiyeline sahiptir. Öyle ki; mekanın içindekiler kadar mekanın kendisi de oyuncak olabilir.

9. Çocuklar kendilerini güvende hissetmek isterler. Mekanın güvenliği bu açıdan önemlidir. İç mekanda bunu sağlamak eğitimli oyun liderlerince daha kolay olmakla beraber özellikle diş mekan oyun alanlarında oyun alanlarının çevresel güvenlik önlemleri sağlanmalıdır. Dış mekan oyun alanlarına kedi, köpek gibi hayvanlar girebilmekte bu durum çoğu zaman çocuklar açısından rahatsız edici de olabilmektedir. Bu açıdan oyun alanının bu anlamda çevrelenmiş olması, yangın söndürme cihazı, acil yardım butonu ya da acil yardım telefon numaralarının bulunduğu tabelalar gibi... Güvenlik tedbirleri gerekmektedir. Ayrıca günümüzde güvenlik probleminin dış mekan oyun alanlarında daha da artmış olması yerel yönetimlerce kameralı takip sistemi gibi uygulamaları da yaygınlaştırmaktadır. M.E.B. ilköğretim kurumlarında güvenlik önlemlerinin alınmasına dair 2018/10 sayılı genelgesi (Erişim, M.E.B. ilköğretim kurumlarında güvenlik önlemlerinin alınmasına dair 2018/10 sayılı genelgesi http://mevzuat.meb.gov.tr/dosyalar/1935.pdf) de bu açıdan eğitim kurumlarında güvenlik önlemlerini zorunlu kılmaktadır. Ayrıca mekanda oluşabilecek teknik ve donanıma bağlı güvenlik problemlerine karşı tedbir alınması da zorunlu kılınmıştır. Böylesi bir durumla karşılaşmamak adına mekanda oluşabilecek yangın vs. gibi tehlikelere karşı alınacak tedbirler M.E.B. yangın önleme ve söndürme yönergesi (Erişim, M.E.B. yangın önleme ve söndürme yönergesi http://mevzuat.meb.gov.tr/dosyalar/766.pdf) ile belirlenmiş ve tüm eğitim kurumlarında uyma zorunluluğu getirilmiştir.

10. Oyun alanlarında kullanılacak aydınlatmanın gözleri yormaması bakımından gün ışı̆̆ı veren ve yeterli sayıda aydınlatma elemanı ile çözülmesi gereklidir. Çoğu dış mekan park ve bahçeler özellikle iklime bağlı olarak gündüz olduğu kadar gece de mekan kullanımına olanak sağlamaktadır. Bu açıdan çevresel aydınlatma elemanı sıklığı ve ş̧ık şiddeti mekanı oyuna elverişli kılmak durumundadır. İç mekan oyun alanlarında ise mümkün olduğunca tercih edilmesi gereken doğal 1şılandırmanın yetersiz kaldığı özellikle spor ve dikkat gerektiren oyunlarda aydınlatma seçimi önemlidir.

11. Özellikle dış mekan oyun alanlarında kum, çakıl, su gibi malzemelerle oynayabilmesi, yeni strüktürler (yapı) kurabilmesi için malzeme ve mekân olanağı sağlanmalıdır. Çünkü büyümenin en önemli kısmı dünyayı deneyimleme olanağına sahip olmak, değiştirmek, bu değişimlerin sonuçlarını görmek ve tüm bu deneyimlerle öğrenmektir. Bu açıdan çocukların çevrelerini değiştirebilme gereksinimleri vardır ve bunu çevresel unsurları kullanarak yapmaktan keyif alırlar. (Alqudah 'tan aktaran Ünal, 2009). Bu durum İç mekan oyun alanlarında ise genellikle yer sorununa alternatif olarak oyun hamuru, lego gibi değişken oyun malzemeleri de kullanılabilmektedir. Ayrıca belirtmek gerekir ki; 'Su' çevresel düzenlemede kullanılan bir peyzaj unsuru olmasının yanında bir oyun elemanı olarak da kullanılabilir özelliktedir. Genellikle göz ardı edilen bu özellik yerinde kullanıldığında 
çocuklar için etkin bir eğlence kaynağı olmaktadır.

12. İç mekan oyun alanlarında mümkün olduğunca doğal havalandırma tercih edilmelidir. Bu açıdan temiz hava sirkülasyonu sağlayacak araç ve açıklıklar düşünülmelidir.

13. Cocuk oyun alanlarında dolașım (sirkülasyon) dönüșümlü ve oyundaki aktivite bölgelerini tarif edici olmalıdır. Temiz hareket alanına sahip ve oyun araçlarının etrafında engel bulunmayan alanlar olmalıdır (Alqudah 'tan akt. Ünal 2009). Ayrica oyun alanlarında özellikle diş mekan çözümlerinde oyun dişı araç ve kişilerin oyuna müdahil olmadan geçiş ve dolaşım sirkülasyonu da düşünülmelidir.

14. Çocuğa keşfetme, gözlem yapma, problem çözme, deneme-yanılma üzerinden gelişme ve öğrenme firsatları sunan mekanlar gerekmektedir. Böylelikle çocuklar yeni becerileri test edebilme olanağına sahip olmaktadırlar. Her yeni mücadeleyi kazanma durumu ise, vücuduyla neler yapabileceğini keşfeden çocuğun özgüvenini kazanmasını sağlamaktadır (Alqudah 'tan akt. Ünal 2009). Bu açıdan oyun alanlarının tırmanma, tutunma ve sallanma ya da denge sağlama gibi olanaklara sahip olması tercih edilmektedir. Ancak bu konuda güvenlik sağlanmalı alttaki yüzey düşmeye karşı güvenli ve yumuşak bir malzeme seçilmelidir.

15. Oyun alanlarının dıș mekanda yoğun trafikten uzak mekanlarda olması bir avantajdır. Trafiğe yakın oyun alanlarında hava kirliliği, egzoz, duman, akan trafik gürültüsü söz konusu olmaktadır. Bu olumsuz durum ağaçlandırma ve yerinde bitkilendirme ile kontrol edilebilir.

16. Mekanda uygun oturma yerleri ve araçları seçilmelidir. Çünkü davranış görüntüleri üzerine yapılan araştırmalar, oyun alanlarında oturma ve konuşmanın başlıca işlevlerden olduğunu göstermektedir. Oturma alanları çocukların dış mekan aktivitelerinin dörtte biri oranındadır (Alqudah 'tan akt. Ünal 2009).

17. Oyun alanlarının onları çocuklar için kolayca hatırlanabilen güçlü bir imgesi olması gerekmektedir. Çocuk için evinin dışında kendisine ait bir mekân hissi çocuk kimliği ve psikolojisi açısından önemlidir. Bir oyun alanı bunu karşılayabiliyorsa oyun alanının bir imgesi yani hemen algılanan bir karakterinden söz edilebilmektedir (Alqudah 'tan akt. Ünal 2009). Örgün eğitim kurumları hem çocuklar üzerinde tercih sebebi olması açısından hem de okul kimliğinin oluşturulması konusunda bunu kullanabilme avantajına sahiptirler.

18. Çocuk oyun alanlarında engelli çocukların da kullanabileceği alanlar düşünülmeli bu açıdan gerekli ulaşım sirkülasyonu oluşturulmalıdır.

\section{Sonuç ve Öneriler}

Çocukluk dönemi, içinde çocuğun temel gereksinimi olan oyunu barındırmak zorundadır. Bu süre örgün eğitimde nispeten kısalmış görünse de daha verimli ve kaliteli zaman geçirme firsatı olarak karşılanabilmektedir. Bu anlamda örgün eğitimde yer alan oyun alanları çocuklar için iyi düşünülmüş mekansal düzenlemeler olmak durumundadırlar.

Çocuk oyun alanları genel anlamda dış mekanda hareketli oyunlara yönelik açık hava oyunları şeklinde düşünülmektedir. Oysaki çocuk için oyun sadece harekete dayalı değildir. Çocuğun düşünebildiğii, geliştirebildiği, müdahil olup her anlamda eğlence unsuru olarak kullanabildiği ölçüde bir olgudur. Bu anlamda çocuğun bulunduğu her mekanı potansiyel oyun alanı olarak kullanma durumu olsa da bunu en sağlıklı kullandığı alanlar ayrılmış veya bu anlamda tasarlanmış oyun mekanlarıdır. Örgün eğitim kurumları eğitimli oyun liderleri olan öğretmenler sayesinde çocukluk dönemindeki bireyin harekete dayalı gelişimi kadar, aklen ve ruhen de eğitilmesi ile ilgilenmektedir. Bunun en etkin öğrenme yolu da oyunu kullanmaktır. Sınırsız oyun potansiyeline sahip çocuklar için her oyun türüne yönelik özel mekan oluşturmak mümkün olmamakla birlikte; ihtiyaca cevap verebilir nitelikte mekanlar oluşturmak yerinde bir 
çözüm olmaktadır. Bu anlamda oyun mekanları ihtiyacının karşılanmasına yönelik belirli tasarım standart ve kriterlerini taşımak durumundadırlar. Oyun için seçilen mekan, kullanıcı sayısı, oyun türüne göre mekanda ve mekansal donanımda kullanılan malzeme, ergonomik oyun elemanları, doğal ve peyzaj unsurlarının kullanılması, mekanın güvenliği ve mekansal malzeme güvenliği, iklim koşullarına uygunluk, çocuk açısından ilgi çekici oyun alanı oluşturma, mekanda kullanılan biçim, renk ve ekipmanlar, aydınlatma çözümü havalandırma çözümü, engelli kullanımına yönelik teknik çözümler, mekan içi ve çevresel sirkülasyon, yerinde kentsel donatı düzenlemeleri gibi konular önemli olmaktadır. Sonuç olarak da mekansal düzenleme ve kurguya bağlı olarak mekansal nitelik ve kalite oluşmaktadır. Örgün eğitimde oyun mekanlarının niteliği ve kalitesi farklı bir araştırma konusu olmakla beraber, çocuklara sunulan oyun mekanları içinde örgün eğitimdeki oyun mekanları daha fazla dikkat isteyen tasarımlar olmaktadır. Çünkü bu mekanlar oyun için ayrılan sınırlı zamanlarda nitelikli ve kaliteli oyun zamanları sunmakla birlikte eğitimde oyunu kullanabilmek adına da gereklidirler.

Ülkemizde temel eğitimin bir parçası olmaktan ziyade eğitime motivasyon olarak kullanılan oyun ve buna bağlı mekansal yapılanma yerinde ve ihtiyaca yönelik sağlanmak durumundadır. Çünkü doğal bir hak olan 'Çocukluğunu İyi Yaşamak' her çocuğun hakkıdır ve iyi bir çocukluk dönemi toplumların bugünleri ve gelecekleriyle ilgilidir. Nitekim çocukluğunu iyi yaşamış bireyler de gelecekte iyi toplumları oluşturur. 


\section{KAYNAKÇA}

Aksoy Y. (2014). “Türkiye'de Yeşil Alanlarla ilgili Yasal Düzenlemeler” İstanbul Ticaret Üniversitesi Fen Bilimleri Dergisi 26 (2014) 1-20.

Altan, İ. (2005). Mimarlıkta Mekân Kavramı. Ofis Yayınları, İstanbul 2005.

Ayan S. \& Ulaş M. (2015). "The Examination of Playground Equipments Which are Used in Turkey according to The Models in Developed Countries”. Route Educational and Social Science Journal 2/3 (2015) 130-145.

Balkış G. N. (2019). “Çocuk Gelişiminde Açık hava Oyunlarının Önemi”. https://okul.com.tr/okul-oncesi/ makaleleri/cocuk-gelisiminde-acik-hava-oyunlarinin-onemi-480 Erişim Tarihi: 04 Mayıs 2019.

Ching F. D. K. (2004). Mimarlık Biçim Mekan ve Düzen. Yapı yayınları, İstanbul 2004.

Çırak Yıımaz M. (2008). 'Mimaride Biçimin Görsel Etkisi: Tasarımcı hedefi ve kullanıcı üzerinden bir Araştırma'. Yüksek Lisans Tezi, Selçuk Üniversitesi F.B.E., Konya 2008.

Duman G., Koçak N. (2013). “Çocuk Oyun Alanlarının Biçimsel Özellikleri Açısından Değerlendirilmesi: Konya İli Örneği”. Türk Eğitim Bilimleri Dergisi 11/1 (2013) 64-81.

Fanuscu E. M. (1994). “Çocuk Oyun Alanları”. ITÜ Orman Fakültesi Dergisi 1/2 (1994) 145-153.

Gür Ş.Ö. \& Zorlu T. (2002). Çocuk Mekânları. Yem Yayınları, İstanbul 2002.

Hasol D. (2002). Ansiklopedik Mimarlık Sözlüğ̈̈. YEM yayınları, İstanbul 2002.

Korkmaz E. (2009). Oyunun Çocuk Gelişimine Etkisi ve Çocuk Oyun Alanları Tasarım Kriterleri ; http://www.planlama.org/index.php/aratrmalar/makaleler/60-oyunun-cocuk-geliimine-etkisi-vecocuk-oyun-alanlar-tasarm-kriterleri Erişim Tarihi: 30 Temmuz 2019.

Kök M., Koçyiğit S. \& Tuğluk M. (2007). "Çocuğun gelişim sürecinde eğitsel bir etkinlik olarak Oyun”. KKEFD 16 (2007) 324-242.

Ormanlıŏglu M. (1999). 'Niçin Oyun? Çocuğun Gelişiminde ve Çocuğu Tanımada Oyunun Önemi', Özne Yayınları. İstanbul 1999.

Pilten P. \& Pilten G. (2013). "Okul Çağı Çocuklarının Oyun Kavramına İlişkin Algılarının ve Oyun Tercihlerinin Değerlendirilmesi”. Mersin Üniversitesi Eğitim Fakültesi Dergisi, 9/2 (2013) 15-31.

Tekkaya E (2001). “Tasarlanmış Çocuk Hakları; Ankara Çocuk Oyun Alanları”. Milli Eğitim Dergisi 151 (2001) http://dhgm.meb.gov.tr/yayimlar/dergiler/Milli_Egitim_Dergisi/151/tekkaya.htm. Erişim Tarihi: 09 Mayıs 2019.

Ünal M. (2009). “Çocuk Gelişiminde Oyun Alanlarının Yeri ve Önemi”. İnönü Üniversitesi Eğitim Fakültesi Dergisi 10/2 (2009) 95-109.

Yılmaz S. \& Bulut Z. (2003). "Kentsel mekânlarda çocuk oyun alanlarının yeri ve önemi: Erzurum örneğii”. Milli Eğitim Dergisi 158. http://dhgm.meb.gov.tr/yayimlar/dergiler/Milli_Egitim_Dergisi/158/yilmaz.htm Erişim Tarihi: 30 Temmuz 2019.

\section{Internet Kaynakları}

URL 1 https://www.unicef.org/turkey/crc/

URL 2 https://www.ekipnormarazon.com/makalelerimiz/oyun-ve-cocuk (Norma RAZON, Eğitim Danışmanı - Pedagog Okul Öncesi Eğitimde Oyunun, Oyunda Yetişkinin İşlevi)

URL 3 https://www.egitimgen.com/2019/03/30/egitimde-oyun-ve-etkileri/

URL 4 https://www.naeyc.org NationalAssociationfortheEducation of YoungChildren,USA

URL 5 https://iedb.meb.gov.tr/meb_iys_dosyalar/2015_08/17032245_2015asgaritasarmklavuzu.pdf

URL 6 M.E.B. ilköğretim kurumları yönetmeliği http://mevzuat.meb.gov.tr/dosyalar/1703.pdf

URL 7 M.E.B. ilköğretim kurumlarında güvenlik önlemlerinin alınmasına dair 2018/10 sayılı genelgesi http://mevzuat.meb.gov.tr/dosyalar/1935.pdf

URL 8 M.E.B. yangın önleme ve söndürme yönergesi http://mevzuat.meb.gov.tr/dosyalar/766.pdf 